\title{
Mengukur kinerja keuangan pada UKM akibat pandemi Covid-19
}

\author{
Bertha Silvia Sutejo \\ Jurusan Manajemen Fakultas Bisnis dan Ekonomika Universitas Surabaya \\ bertha@staff.ubaya.ac.id \\ Marwin Antonius Rejeki Silalahi* \\ Jurusan Manajemen Fakultas Bisnis dan Ekonomika Universitas Surabaya \\ marwin.antonius@staff.ubaya.ac.id \\ *Penulis Korespondensi \\ Submitted: Feb 15, 2021; Reviewed: Feb 21, 2021; Accepted: Mar 25, 2021
}

\begin{abstract}
Competition is increasing from time to time between SMEs (Small and Medium-Sized Enterprieses), for this reason, this research was conducted by measuring SMEs' financial performance in Surabaya due to the impact of the Covid-19 virus. There are four variables analyzed, namely innovative, risk-taking, proactiveness, and competitive aggressiveness. The weaknesses of SMEs are generally in terms of managerial abilities, capital, and human resources. Apart from this, aspects outside the company are one of the causes of SMEs' reduced performance in Indonesia. This study aims to strengthen the results of previous research. The results of this study are used to help the community, especially investors and academics, to understand the importance of entrepreneurship in improving the financial performance of SMEs during the Covid-19 pandemic. This research scale was adopted from existing literature. The research data used secondary data. The research method used was purposive sampling. This study uses reliability and validity tests to measure the scale, classic assumption tests to assess the feasibility of data, and hypothesis testing using multiple regression tests. The results of this study found that innovation, risk-taking, and proactiveness affect financial performance, while competitive aggressiveness does not affect financial performance.
\end{abstract}

Keywords: competitive aggressiveness; financial performance; innovation; proactiveness; risk-taking; SMEs

Abstrak: Persaingan yang semakin meningkat dari waktu ke waktu antara UKM (Usaha Kecil dan Menengah), untuk itu penelitian ini dilakukan dengan mengukur kinerja keuangan UKM di Surabaya akibat dampak dari virus Covid-19. Terdapat empat variabel yang dianalisis, yaitu innovative, risktaking, proactiveness, dan competitive aggressiveness. Kekurangan UKM umumnya dalam hal kemampuan manajerial, modal, dan sumber daya manusia. Selain hal-hal tersebut, aspek di luar perusahaan merupakan salah satu penyebab berkurangnya kinerja UKM di Indonesia. Penelitian ini bertujuan untuk menguatkan hasil penelitian sebelumnya dan hasil penelitian ini digunakan untuk membantu masyarakat, khususnya investor dan akademisi, untuk memahami pentingnya enterpreneurship di dalam meningkatkan kinerja keuangan UKM pada masa pandemi Covid-19. Skala penelitian ini diadopsi dari literatur yang sudah ada. Data penelitian ini menggunakan data sekunder, dengan metode penelitian yang digunakan adalah purposive sampling. Penelitian ini menggunakan uji reabilitas dan validitas untuk mengukur skala, uji asumsi klasik untuk menilai kelayakan data, serta uji hipotesis menggunakan analisis regresi berganda. Hasil penelitian ini, didapatkan bahwa innovative, 
risk-taking, dan proactiveness memengaruhi kinerja keuangan, sedangkan competitive aggressiveness tidak berpengaruh terhadap kinerja keuangan.

Kata kunci: competitive agressiveness; inovasi; kinerja keuangan; proactiveness; risk-taking; UKM

\section{PENDAHULUAN}

Ratnawati \& Hikmah (2013) menyatakan bahwa perekonomian di Indonesia umumnya dikuasai oleh UKM dengan persentase melebihi 95\%. Untuk itu, UKM masih memegang cakupan yang sangat penting bagi perekonomian Indonesia. Barang dan jasa yang dibutuhkan oleh masyarakat dan dikonsumsi baik itu skala besar, sedang, dan kecil, memiliki faktor penting dalam membantu pertumbuhan ekonomi di Indonesia. UKM memegang peranan penting untuk mengurangi tingkat pengangguran yang berakibat meningkatkan taraf hidup yang lebih baik bagi masyarakat Indonesia. Menurut Mustikowati \& Tysari (2014), UKM di Indonesia memiliki kekurangan dalam hal daya saing. Hal ini dikarenakan kurangnya inovasi, kreativitas, dan kecekatan dalam melihat kesempatan yang ada di sekitarnya. Kekurangan UKM umumnya dalam hal kemampuan manajerial, modal, dan sumber daya manusia. Selain hal-hal tersebut, faktor di luar perusahaan merupakan faktor penyebab berkurangnya kinerja UKM di Indonesia. Tujuan penelitian ini adalah agar para UKM lebih peka terhadap kondisi lingkungan sekitar mereka serta lebih mengenal kekurangan dan kekuatan dari usaha mereka. Penelitian ini juga diharapkan sebagai bahan referensi untuk menunjang penelitian yang terkait dengan UKM, khususnya pada masa pandemi Covid19.

Berdasarkan latar belakang, penelitian ini memfokuskan tujuan untuk melakukan pengujian mengenai pengaruh Corporate Entrepreneurship (CE) terhadap kinerja perusahaan Usaha Kecil Menengah (UKM) di Surabaya akibat dampak dari pandemi Covid-19, sehingga penelitian ini memiliki perbedaan dengan penelitian-penelitian sebelumnya, dikarenakan aspek lingkungan yaitu pandemi Covid-19. Dari gap tersebut kemudian dijabarkan dalam permasalahan-permasalah minor sebagai berikut:

a. Apakah proactiveness berpengaruh pada kinerja perusahaan UKM di Surabaya akibat dampak dari virus Covid-19?

b. Apakah risk taking berpengaruh pada kinerja perusahaan UKM di Surabaya akibat dampak dari virus Covid-19?

c. Apakah innovativeness berpengaruh pada kinerja perusahaan UKM di Surabaya akibat dampak dari virus Covid-19?

d. Apakah competitive aggressiveness berpengaruh pada kinerja perusahaan UKM di Surabaya akibat dampak dari virus Covid-19?

Menurut Saragih (2017), kebaruan (novelty) dan perbaikan (improvement) merupakan kriteria inovasi, nilai guna, kondisi, dan aplikasi merupakan suatu kebaruan yang dimaksud di sini. Saragih (2017) juga berpendapat bahwa incremental dan radikal merupakan proses yang dipertimbangkan dalam hal improvement untuk menciptakan suatu produk baru. Inovasi adopsi, inovasi yang disebarkan, serta proses penciptaan merupakan pengertian lain dari inovasi itu sendiri. Wahid (2017) berpendapat bahwa untuk mencapai tujuan dari aktivitas-aktivitas, aktivitas tersebut di dalamnya harus terdapat motivasi sebagai penggerak dalam melakukan kegiatan kewirausahaan, hal ini juga dikatakan sebagai kesiapsiagaan. Berdasarkan kondisi atas mewabahnya virus Covid-19 di dunia, maka secara tidak langsung akan memengaruhi kinerja keuangan dan kemampuan UKM di Indonesia. Aktan \& Bulut (2008) menjelaskan bahwa keunggulan kompetitif merupakan cara untuk beradaptasi dan juga strategi dalam persaingan global pada saat ini, dan hal ini dikenal dengan kemampuan kewirausahaan perusahaan (Corporate Entrepreneurship atau disingkat CE). Menurut Hadiyati (2011), Ratnawati \& Hikmah (2013), Sutejo (2015), dan Saragih (2017), CE adalah sekumpulan kebijakan, proses, dan karakteristik organisasi perusahaan yang mana organisasi mencoba untuk berusaha mengaktualisasi sebagai pioneer ide inovatif dalam produk, proses, struktur, dan pasar. Tabel 1 adalah beberapa hasil penelitian terdahulu terkait dengan CE dan kinerja keuangan perusahaan. 
Tabel 1. Penelitian terdahulu

\begin{tabular}{|c|c|c|}
\hline Tahun & Peneliti & Temuan \\
\hline 2008 & Aktan \& Bulut & $\begin{array}{l}\text { Melakukan penelitian dengan sampel perusahaan dari Turki, } \\
\text { variabel yang diuji adalah } 4 \text { dimensi kemampuan } \\
\text { kewirausahaan (innovativeness, risk taking, proactiveness, } \\
\text { dan competitive aggressiveness). Hasil yang didapatkan } \\
\text { adalah kemampuan kewirausahaan berpengaruh positif } \\
\text { terhadap kinerja keuangan perusahaan. }\end{array}$ \\
\hline 2011 & Hadiyati & $\begin{array}{l}\text { Variabel inovasi dalam kewirausahaan dipengaruhi oleh } \\
\text { kreativitas, variabel kewirausahaan dipengaruhi secara } \\
\text { parsial oleh kreativitas, dan variabel kewirausahaan } \\
\text { dipengaruhi oleh inovasi secara parsial, sedangkan } \\
\text { kewirausahaan dipengaruhi secara besar oleh inovasi. }\end{array}$ \\
\hline 2013 & Ratnawati \& Hikmah & $\begin{array}{l}\text { Penelitian terhadap UKM Kabupaten dan Kota Semarang } \\
\text { dengan menguji faktor-faktor yang memengaruhi kinerja } \\
\text { UKM. Hasil penelitiannya adalah kinerja dipengaruhi oleh } \\
\text { penghargaan, kerjasama, dan peraturan pemerintah. Kinerja } \\
\text { secara keseluruhan dipengaruhi oleh pasar, kecanggihan } \\
\text { teknologi, permodal, informasi, jaringan, kesahan menurut } \\
\text { hukum, perencanaan bisnis, kemampuan berwirausaha, dan } \\
\text { support pemerintah. }\end{array}$ \\
\hline 2015 & Sutejo & $\begin{array}{l}\text { Hasil penelitiannya adalah kinerja keuangan dipengaruhi } \\
\text { oleh kemampuan kewirausahaan. Selain itu, kinerja } \\
\text { keuangan dipengaruhi oleh innovativeness, proactiveness, } \\
\text { dan risk-taking. Satu dimensi CE (competitive } \\
\text { aggressiveness) dihilangkan karena hasil jawaban } \\
\text { pertanyaannya tidak relevance. }\end{array}$ \\
\hline 2016 & Ranto & $\begin{array}{l}\text { Hasil penelitiannya adalah kinerja UKM dipengaruhi oleh } \\
\text { innovativeness, risk taking, dan proactiveness. UKM dalam } \\
\text { kuliner yang berlokasi di Bantul. }\end{array}$ \\
\hline 2017 & Saragih & $\begin{array}{l}\text { Hasil penelitiannya adalah wirausaha sosial sangat } \\
\text { membutuhkan modal dasar dalam melakukan usahanya, } \\
\text { dengan melihat ide kreatif dan inovatif. }\end{array}$ \\
\hline 2017 & Wahid & $\begin{array}{l}\text { Hasil penelitiannya adalah kinerja operasional dipengaruhi } \\
\text { oleh kemampuan dalam menyusun laporan keuangan. } \\
\text { Sampel usahanya adalah UKM yang berlokasi di } \\
\text { Taksimalaya. }\end{array}$ \\
\hline
\end{tabular}

Sumber: Diolah dari berbagai sumber 


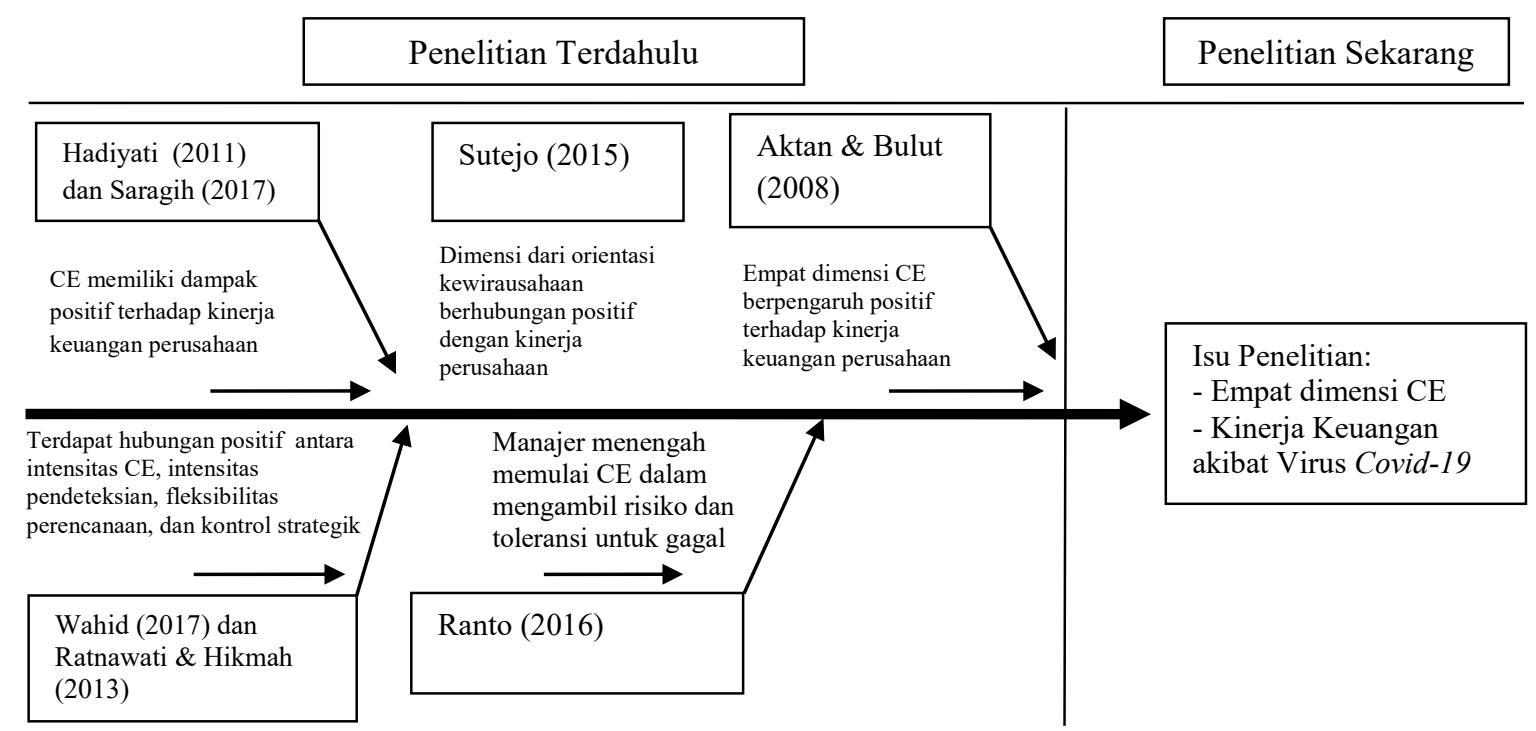

Gambar 1. Bagan alir penelitian terdahulu

Sumber: Diolah dari berbagai sumber

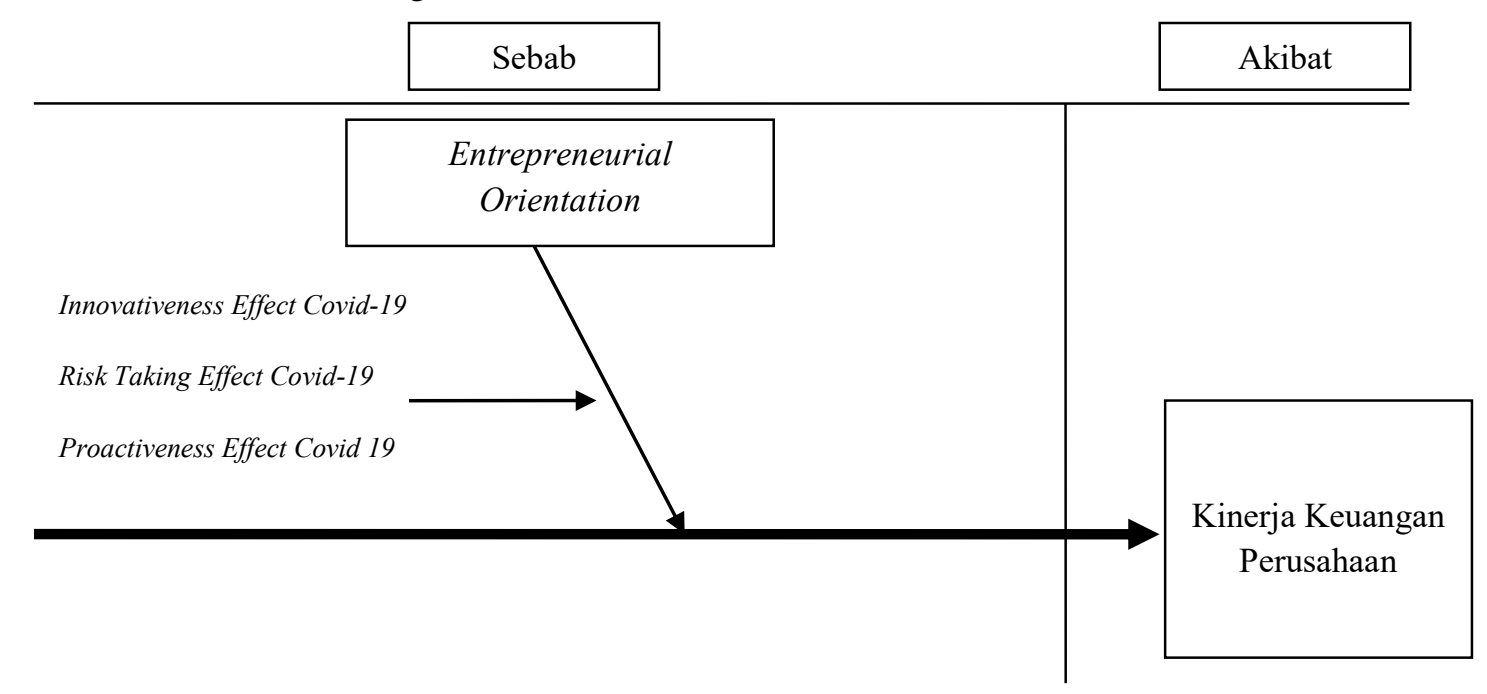

Gambar 2. Diagram alir penelitian

Sumber: Diolah dari berbagai sumber

Berdasarkan analisis literatur, maka penelitian ini mengembangkan hipotesis mayor sebagai berikut: H1: Innovativeness dalam CE memengaruhi kinerja keuangan akibat dampak dari virus Covid-19.

Dengan adanya pandemi virus Covid-19, maka secara terpaksa, pihak-pihak UKM harus memutar otak dan melakukan banyak inovasi demi kelangsungan usaha UKM mereka. Perilaku kewirausahaan yang di dalamnya terdapat inovasi, maka bisa disebut sebagai inovatif (Wolff et al., 2015). Kegiatan yang berkaitan dengan teknologi dan ilmu pengetahuan yang baru atau penelitian yang dikembangkan atau perekayasaan dengan menerapkan nilai praktis dan konteks ilmu itu sendiri ke dalam usaha atau proses produksi, hal ini tercantum di dalam UU No. 18 tahun 2002 (Peraturan BPK RI, 2002).

H2: Risk taking dalam CE memengaruhi kinerja keuangan akibat dampak dari virus Covid-19.

Kondisi perekonomian yang lesu, dikarenakan adanya PSBB (Pembatasan Sosial Berskala Besar), apalagi semakin meningkatnya persaingan antar sesama UKM, maka pengusaha UKM harus berani mengambil risiko yang ada. Ketika setiap UKM berjuang untuk menjadi first mover, itu seperti memerebutkan pai di dalan kantung yang kecil (Narver et al., 2004; dalam Ranto, 2016). Pengambilan risiko ialah salah satu dimensi yang penting dari entrepreneurial orientation. Dalam memerebutkan risiko yang tidak pasti sama halnya dengan pengambilan risiko yang tidak jelas, tujuan yang tidak pasti, 
dan bisa berubah-ubah (Pratono, 2018). Untuk itu, diperlukan suatu evaluasi risiko yang melingkupi konsep pengambilan (Franco \& Haase, 2013).

H3: Proactiveness dalam CE memengaruhi kinerja keuangan akibat dampak dari virus Covid-19.

Menurut Utami \& Kusmantini (2012), faktor kualitas lingkungan adalah penyebab lahirnya evolusi dalam hal kualitas yang di dalamnya ada kemampuan bersaing, dengan hal ini menyebutkan perubahan makna dari TQM atau Total Quality Management terhadap lingkungan (TQEM/ Total Quality Environment Management), di situasi saat ini, di mana pada tahun 2020 adanya pandemi Covid-19 yang mengubah lingkungan secara langsung dan tidak langsung, sehingga menimbulkan persaingan yang semakin ketat, khususnya dalam UKM di Indonesia.

H4: Competitive aggressiveness dalam CE memengaruhi kinerja keuangan akibat dampak dari virus Covid-19.

Menurut Wulandary et al. (2018), kemampuan bersaing para UKM merupakan suatu bentuk dari agresivitas kompetitif. Persaingan yang kompetitif ini erat kaitannya dengan pelaku usaha, yang mana pelaku usaha akan melakukan berbagai cara untuk lebih unggul dari pelaku usaha lainnya. Hal ini menyebabkan agresivitas kompetitif pada saat terjadinya wabah virus Covid-19 menjadi sangat tinggi di dalam berbagai industri.

\section{METODE}

Penelitian ini menggunakan empat variabel bebas, yaitu innovativeness, risk taking, proactiveness, dan competitive aggressiveness, sedangkan variabel terikatnya adalah kinerja keuangan. Penelitian ini menggunakan pendekatan kualitatif, yang mana penelitian ini melakukan deep interview dan kuesioner. Penelitian ini dibuat dengan spesifik yang mana pemilihan sampel penelitian dan instrumen pengumpulan data yang terukur menjadi ciri khas penelitian ini. Penelitian ini terdiri dari beberapa pertanyaan yang bersifat investigasi dan hipotesa yang bersifat terukur.

Teknik pemilihan informan dengan cara purposive judgment sampling atau pemilihan secara sengaja dengan pertimbangan informan adalah pemilik UKM di Surabaya. Setelah menetapkan sampel, prosedur penelitian yang selanjutnya adalah menyebarkan kuesioner kepada pelaku UKM di Surabaya melalui aplikasi Google Form dan tanya jawab dengan aplikasi Whatsapp. Teknik analisis data dengan teknik pengujian statistik menggunakan uji regresi linier berganda. Berikut ini model penelitian yang akan diuji dalam penelitian ini:

$\mathrm{KK}=\mathrm{a}+\mathrm{b} 1 \mathrm{I}+\mathrm{b} 2 \mathrm{RT}+\mathrm{b} 3 \mathrm{PA}+\mathrm{b} 4 \mathrm{CA}+\mathrm{e}$

Keterangan:

KK = Kinerja Keuangan

$\mathrm{I}=$ Innovativeness

$\mathrm{RT}=$ Risk Taking

$\mathrm{PA}=$ Proactiveness

$\mathrm{CA}=$ Competitive Agressiveness

$\mathrm{e}=$ error

\section{HASIL DAN PEMBAHASAN}

\subsection{Hasil penelitian}

Berdasarkan data yang didapatkan melalui deep interview dan kuesioner, melalui 154 responden UKM yang berdomisili di Surabaya, yang mana menurut Suryani \& Hendryadi (2015) bahwa penelitian dengan metode survei dan kuesioner, minimum jumlah sampel yang digunakan di atas 100 orang responden, dan pada penelitian ini jumlah responden yang digunakan adalah 154 orang responden UKM, 
untuk itu jumlah ini sudah mewakili populasi sampel yang beragam dari UKM yang terdaftar di KADIN (Kamar Dagang dan Industri Indonesia) Surabaya, yang terdiri dari jenis kelamin, usia, jenis perusahaan, jenis usaha, skala perusahaan, jabatan, lama bekerja, dan divisi bekerja. Statistik deskriptif untuk kategori responden dengan jenis gender pria sebanyak 45,5\% atau sebanyak 71 orang responden pria dan wanita sebanyak $54,5 \%$ atau sebanyak 83 orang responden wanita. Kategori usia responden: responden dengan usia $<30$ tahun sebanyak 55,2\% atau sebanyak 85 orang responden, responden dengan usia 30-50 tahun sebanyak 35,7\% atau sebanyak 55 orang responden, responden dengan usia 50-65 tahun sebanyak 8,4\% atau sebanyak 13 orang responden, dan sisanya responden dengan usia di atas 65 tahun sebanyak $0,6 \%$ atau sebanyak 1 orang responden. Kategori jenis perusahaan responden: responden dengan perorangan sebanyak $53,2 \%$ atau sebanyak 82 orang responden, responden dengan UD (Usaha Dagang) sebanyak $16,2 \%$ atau sebanyak 25 orang responden, responden dengan CV (Comanditaire Venootschap) sebanyak 4,5\% atau sebanyak 7 orang responden, responden dengan korporasi (PT) sebanyak 5,8\% atau sebanyak 9 orang responden, dan responden dengan jenis perusahaan lainnya sebanyak $20,1 \%$ atau sebanyak 31 orang responden. Kategori dengan jenis usaha responden: responden dengan usaha dagang sebanyak $26,6 \%$ atau sebanyak 41 orang responden, responden dengan usaha jasa sebanyak $11 \%$ atau sebanyak 17 orang responden, responden dengan usaha manufaktur sebanyak $14,3 \%$ atau sebanyak 22 orang responden, responden dengan usaha dagang dan manufaktur sebanyak 30,5\% atau sebanyak 47 orang responden, serta responden dengan usaha lainnya sebanyak $17,5 \%$ atau sebanyak 27 orang responden.

Kategori dengan skala perusahaan responden: responden dengan skala mikro sebanyak $85,1 \%$ atau sebanyak 131 orang responden, responden dengan skala kecil sebanyak $9,1 \%$ atau sebanyak 14 orang responden, responden dengan skala menengah sebanyak 5,2\% atau sebanyak 8 orang responden, dan responden dengan skala besar sebanyak $0,6 \%$ atau sebanyak 1 orang responden. Kategori dengan jabatan responden: responden dengan jabatan sebagai pemilik sebanyak $73,4 \%$ atau sebanyak 113 orang responden, responden dengan jabatan sebagai top manager sebanyak 3,2\% atau sebanyak 5 orang responden, responden dengan jabatan sebagai middle manager sebanyak $0,6 \%$ atau sebanyak 1 orang responden, responden dengan jabatan sebagai supervisor sebanyak 1,9\% atau sebanyak 3 orang responden, responden dengan jabatan sebagai partner/ investor sebanyak 3,9\% atau sebanyak 6 orang responden, dan responden dengan jabatan lainnya sebanyak 16,9\% atau sebanyak 26 orang responden. Kategori responden dari lamanya bekerja: responden yang lamanya bekerja 0-3 tahun sebanyak 50,6\% atau sebanyak 78 orang responden, responden yang lamanya bekerja 3-5 tahun sebanyak $21,4 \%$ atau sebanyak 33 orang responden, responden yang telah bekerja di UKM sekitar 5-10 tahun sebanyak 14,9\% atau sebanyak 23 orang responden, responden yang lamanya bekerja 10-15 tahun sebanyak 7,8\% atau sebanyak 12 orang responden, responden yang bekerja 15-25 tahun sebanyak 3,2\% atau sebanyak 5 orang responden, dan responden yang bekerja 25-50 tahun sebanyak 1,9\% atau sebanyak 3 orang responden. Kategori responden dilihat dari divisi bekerja: responden yang merupakan pemilik usaha UKM sebanyak 68,2\% atau sebanyak 105 orang responden, responden yang bekerja di divisi operation sebanyak $3,9 \%$ atau sebanyak 6 orang responden, responden yang bekerja di divisi pemasaran sebanyak $5,8 \%$ atau sebanyak 9 orang responden, responden yang bekerja di divisi sumber daya manusia sebanyak 4,5\% atau sebanyak 7 orang responden, responden yang bekerja di divisi supporting (keuangan, akuntansi, pajak) sebanyak 5,8\% atau sebanyak 9 orang responden, dan responden yang bekerja di divisi lainnya sebanyak $11,7 \%$ atau sebanyak 18 orang responden.

Penelitian ini menggunakan uji validitas dan reliabitas. Untuk menguji apakah 35 item pertanyaan yang dijawab oleh 154 orang responden, valid atau tidak dan metode alat pengukuran yang dipakai dalam penelitian ini sudah sesuai atau tidak. Penelitian ini menggunakan SPSS, yang di dalamnya terdapat uji validitas dan uji reliabilitas. Hasil uji validitas, dengan melihat nilai Pearson Correlation dibandingkan dengan r-tabel 154 pada test of significance two tailed (5\%), didapatkan hasil r-tabelnya adalah 0,1572 . Nilai valid, jika pearson correlation > nilai r-tabel, demikian sebaliknya. Seperti tersaji pada Tabel 2 di bawah ini.

Tabel 2. Hasil uji validitas

\begin{tabular}{lllll}
\hline Q & Correlations & Qtabel & r-tabel & Result \\
\hline Q1 & Pearson Correlation & 0,596 & 0,1572 & Valid
\end{tabular}




\begin{tabular}{lllll} 
Q2 & Pearson Correlation & 0,620 & 0,1572 & Valid \\
Q3 & Pearson Correlation & 0,163 & 0,1572 & Valid \\
Q4 & Pearson Correlation & 0,506 & 0,1572 & Valid \\
Q5 & Pearson Correlation & 0,642 & 0,1572 & Valid \\
Q6 & Pearson Correlation & 0,641 & 0,1572 & Valid \\
Q7 & Pearson Correlation & 0,637 & 0,1572 & Valid \\
Q8 & Pearson Correlation & 0,617 & 0,1572 & Valid \\
Q9 & Pearson Correlation & 0,688 & 0,1572 & Valid \\
Q10 & Pearson Correlation & 0,730 & 0,1572 & Valid \\
Q11 & Pearson Correlation & 0,433 & 0,1572 & Valid \\
Q12 & Pearson Correlation & 0,262 & 0,1572 & Valid \\
Q13 & Pearson Correlation & 0,370 & 0,1572 & Valid \\
Q14 & Pearson Correlation & 0,592 & 0,1572 & Valid \\
Q15 & Pearson Correlation & 0,588 & 0,1572 & Valid \\
Q16 & Pearson Correlation & 0,376 & 0,1572 & Valid \\
Q17 & Pearson Correlation & 0,655 & 0,1572 & Valid \\
Q18 & Pearson Correlation & 0,761 & 0,1572 & Valid \\
Q19 & Pearson Correlation & 0,523 & 0,1572 & Valid \\
Q20 & Pearson Correlation & 0,660 & 0,1572 & Valid \\
Q21 & Pearson Correlation & 0,213 & 0,1572 & Valid \\
Q22 & Pearson Correlation & 0,771 & 0,1572 & Valid \\
Q23 & Pearson Correlation & 0,671 & 0,1572 & Valid \\
Q24 & Pearson Correlation & 0,762 & 0,1572 & Valid \\
Q25 & Pearson Correlation & 0,804 & 0,1572 & Valid \\
Q26 & Pearson Correlation & 0,680 & 0,1572 & Valid \\
Q27 & Pearson Correlation & 0,795 & 0,1572 & Valid \\
Q28 & Pearson Correlation & 0,803 & 0,1572 & Valid \\
Q29 & Pearson Correlation & 0,714 & 0,1572 & Valid \\
Q30 & Pearson Correlation & 0,539 & 0,1572 & Valid \\
Q31 & Pearson Correlation & 0,484 & 0,1572 & Valid \\
Q32 & Pearson Correlation & 0,525 & 0,1572 & Valid \\
Q33 & Pearson Correlation & 0,225 & 0,1572 & Valid \\
Q34 & Pearson Correlation & 0,691 & 0,1572 & Valid \\
Q35 & Pearson Correlation & 0,596 & 0,1572 & Valid \\
Qtotal & Pearson Correlation & 1 & & \\
\hline Sumber & Hasil pengolahan SPSs & $5(2020)$ & & \\
& & & & \\
& &
\end{tabular}

Sumber: Hasil pengolahan SPSS 25 (2020)

Setelah dilakukan uji validitas, selanjutnya dilakukan uji reliabilitas dengan melihat Cronbach's alpha, jika nilai Cronbach's alpha > 0,60, dengan begitu kuesioner dinyatakan reliable, demikian sebaliknya. Hasil tes reliabilitas pada penelitian ini adalah nilai Cronbach's alpha $=0,942$, dengan itu kuesioner dalam penelitian ini dinyatakan reliabel.

Tabel 3. Hasil uji reliabilitas

\begin{tabular}{lll}
\hline & $\mathrm{N}$ & $\%$ \\
\hline Valid & 154 & 100 \\
Excluded & 0 & 0 \\
Total & 154 & 100 \\
& Cronbach's Alpha & Nof Items \\
& 0,942 & 35 \\
\hline
\end{tabular}

Sumber: Hasil pengolahan SPSS 25 (2020)

Setelah dilakukan uji validitas dan reliabilitas, kemudian berlanjut ke uji regresi linier berganda. Pada penelitian ini, uji regresi linier berganda dimulai dari koefisien determinasi, didapatkan nilai koefisien determinasi melalui nilai $R$-Square adalah 0,528 yang menunjukkan bahwa proporsi variabel innovative, risk-taking, proactiveness, dan competitive aggressiveness terhadap kinerja keuangan sebesar 52,8\%. 
Hasil tersebut menunjukkan bahwa variabel innovative, risk-taking, proactiveness, dan competitive aggressiveness terhadap kinerja keuangan dapat dijelaskan sebesar 52,8\%, sedangkan sisanya 47,2\% dapat dijelaskan oleh variabel lain yang tidak ada di dalam model regresi linier.

Tabel 4. Hasil uji R-Square

\begin{tabular}{lll}
\hline Model & $\mathrm{R}$ & $R$-Square \\
\hline 1 & 0,727 & 0,528 \\
\hline
\end{tabular}

Sumber: Hasil pengolahan SPSS 25 (2020)

Pada penelitian ini, dilakukan uji F, untuk melihat apakah model regresi ini layak atau tidak, dengan melihat Tabel Anova dalam SPSS, tepatnya pada nilai sig. Nilai sig. pada penelitian ini sebesar 0,000, artinya nilai sig. lebih kecil dari tingkat kesalahan/ error (alpha) 0,05 (yang telah ditentukan), maka dapat dikatakan bahwa model regresi yang diestimasi pada penelitian ini layak. Dalam arti kata bahwa variabel terikat dan variabel bebas dalam penelitian ini cocok untuk dijadikan model penelitian atau dapat dikatakan model penelitian ini sudah fit.

Tabel 5. Hasil uji F

\begin{tabular}{ll}
\hline $\mathrm{F}$ & Sig. \\
\hline 41,715 & 0,000 \\
\hline
\end{tabular}

Sumber: Hasil pengolahan SPSS 25 (2020)

Setelah dilakukan uji $\mathrm{F}$, selanjutnya adalah uji t, untuk melihat apakah variabel terikat dalam penelitian ini dipengaruhi oleh setiap variabel bebas dan model penelitian yang dipakai dalam penelitian ini sudah sesuai atau tidak.

Tabel 6. Hasil uji t

\begin{tabular}{llll}
\hline & $\mathrm{B}$ & $\mathrm{t}$ & Sig. \\
\hline Constant & 11,234 & 3,383 & 0,001 \\
$\mathrm{X} 1$ & 0,466 & 2,507 & 0,013 \\
$\mathrm{X} 2$ & 1,165 & 3,658 & 0,000 \\
X3 & $-0,610$ & $-1,906$ & 0,059 \\
X4 & 0,884 & 5,658 & 0,000 \\
\hline Sumber: Has
\end{tabular}

Sumber: Hasil pengolahan SPSS 25 (2020)

Dari Tabel 6, peneliti dapat melihat nilai konstanta, X1, X2, X3, dan X4, sehingga model dalam penelitian ini adalah:

$\mathrm{KK}=11,234+0,466 \mathrm{I}+1,165 \mathrm{RT}-0,610 \mathrm{PA}+0,884 \mathrm{CA}+\mathrm{e}$

Keterangan:

KK $=$ Kinerja Keuangan

$\alpha=$ Konstanta: 11,234 menunjukkan bahwa variabel Innovative, Risk-Taking, Proactiveness, dan Competitive Aggressiveness, jika nilainya 0, maka kinerja keuangan akan naik sebesar 11,234.

$\beta 1-\beta 4=$ Regresi koefisien

Nilai koefisien I ( $\beta 1)$ adalah 0,466 dengan nilai positif, artinya untuk setiap kenaikan Innovative sebanyak 1 kali, Kinerja Keuangan (KK) akan meningkat sebesar 0,466 dengan asumsi variabel lainnya konstan. Nilai koefisien RT ( $\beta 2$ ) adalah 1,165 dengan nilai positif, artinya untuk setiap kenaikan Risk Taking sebanyak 1 kali, Kinerja Keuangan (KK) akan meningkat sebesar 1,165 dengan asumsi variabel lainnya konstan. Nilai koefisien PA ( $\beta 3$ ) sebesar -0,610 dengan nilai negatif, artinya untuk setiap 1 kali kenaikan Proactiveness, Kinerja Keuangan (KK) akan menurun sebesar 0,610 dengan asumsi variabel lain konstan. Nilai koefisien CA ( $\beta 4$ ) sebesar 0,884 dengan nilai positif, artinya untuk setiap 1 kali kenaikan Competitive Agressiveness, Kinerja Keuangan (KK) akan meningkat sebesar 0,884 dengan asumsi variabel lain konstan. 


\subsection{Pembahasan}

Pada uji t penelitian ini, didapatkan hasil untuk innovative menghasilkan nilai sig. $0,001<0,05$; risk taking menghasilkan nilai sig. $0,013<0,05$; dan proactiveness memiliki nilai sig. $0,000<0,05$. Hasilhasil tersebut menunjukkan bahwa ketiga variabel, innovative, risk taking, dan proactiveness, berpengaruh terhadap kinerja keuangan UKM pada masa pandemi Covid-19. Hasil penelitian ini, sejalan dengan penelitian Aktan \& Bulut (2008), Sutejo (2015), dan Ranto (2016). Variabel competitive aggressiveness memiliki nilai sig. 0,059>0,05, artinya bahwa variabel competitive aggressiveness tidak berpengaruh terhadap kinerja keuangan UKM pada masa pandemi Covid-19. Hasil penelitian ini sejalan dengan Sutejo (2015), yaitu competitive aggressiveness tidak berpengaruh terhadap kinerja keuangan.

Menurut Pakpahan (2020), pandemi Covid-19 belum berakhir dan semua negara terkena dampaknya. Solusinya adalah kita sebagai masyarakat harus tetap menjalankan protokol kesehatan, meskipun vaksin Covid-19 sudah ditemukan, tetapi untuk produksi masal dan distribusi vaksin Covid-19 membutuhkan waktu. Kebijakan jangka panjang dan jangka pendek dari pemerintah Indonesia akan memengaruhi perkonomian, khususnya UKM yang pasti berhubungan dengan peminjaman akan terkena dampaknya. Sementara, strategi jangka panjang difokuskan pada pengenalan dan penggunaan teknologi digital bagi UKM sekaligus persiapan untuk memasuki era Industri 4.0. Karena penelitian ini dilakukan di Indonesia, tepatnya di Surabaya, maka Indonesia merupakan salah satu negara yang terkena dampak dari pandemi Covid-19.

\section{SIMPULAN DAN SARAN}

Beberapa variabel bebas dalam penelitian ini memengaruhi variabel terikat. Variabel bebas (innovative, risk taking, dan proactiveness) memengaruhi variabel terikat (kinerja keuangan) pada masa pandemi Covid-19, karena pada masa pandemi Covid-19 ini UKM di Surabaya dituntut untuk lebih inovatif dalam melakukan promosi dan penjualan secara online serta peka terhadap kebutuhan-kebutuhan masyarakat yang baru muncul akibat adanya Covid-19, misalnya menjual masker, face shield, dan sarung tangan, bahkan jika memungkinkan menjual APD (Alat Perlindungan Diri) untuk tenaga medis di rumah sakit. Selain itu, jika para UKM di Surabaya membuat unit bisnis yang baru seperti menjual masker, face shield, dan sarung tangan, maka mereka harus berani risk taking agar usaha mereka bisa terus berjalan, dikarenakan pandemi Covid-19 ini mengubah kebutuhan masyarakat secara langsung dan juga cara kerja dari offline ke online. Dikarenakan situasi pandemi Covid-19, para UKM khususnya di Surabaya, dituntut untuk memiliki proactiveness, karena semua dijalankan secara online, jadi tidak ada batasan ruang dan waktu di dalam bekerja dan mendapatkan informasi yang real time.

Variabel competitive aggressiveness (variabel bebas) tidak berpengaruh terhadap kinerja keuangan (variabel terikat) UKM di Surabaya pada masa pandemi Covid-19, karena menurut penulis, terlepas dari ada atau tidaknya Covid-19 ini, persaingan akan tetap tinggi antara sesama UKM, yang mana sejak adanya Covid-19 ini semua UKM melakukan promosi dan penjualan secara online, mereka melakukan metode yang sama yaitu online, jadi competitive aggressiveness tidak memengaruhi kinerja keuangan pada masa pandemi Covid-19.

\section{ACKNOWLEDGEMENTS}

Artikel ini terinsipirasi dari penelitian Sutejo (2015), kemudian dikembangkan sesuai dengan keadaan pandemi Covid-19. Penelitian ini juga terjadi berkat para UKM di Surabaya dan LPPM Universitas Surabaya sebagai pihak pemberi dana atas penelitian ini.

\section{REFERENSI}

Aktan, B. \& Bulut, C. (2008). Financial performance impacts of corporate entrepreneurship in emerging markets: A case of Turkey. European Journal of Economics, Finance, and Administrative 
Sciences, 12, 69-79. https://www.researchgate.net/profile/Cagri-Bulut3/publication/228454300_Financial_Performance_Impacts_of_Corporate_Entrepreneurship_in_ Emerging_Markets_A_Case_of_Turkey/links/0912f50ce35155d0bf000000/Financial-

Performance-Impacts-of-Corporate-Entrepreneurship-in-Emerging-Markets-A-Case-ofTurkey.pdf.

Franco, M. \& Haase, H. (2013). Firm resources and entrepreneurial orientation as determinants for collaborative entrepreneurship. Management Decision, 51(3), 680-696. https://doi.org/10.1108/00251741311309724

Hadiyati, E. (2011). Kreativitas dan inovasi berpengaruh terhadap kewirausahaan usaha kecil. Jurnal Manajemen dan Kewirausahaan. https://doi.org/10.9744/jmk.13.1.8-16

Mustikowati, R. I. \& Tysari, I. (2014). Orientasi kewirausahaan, inovasi, dan strategi bisnis untuk meningkatkan kinerja perusahaan (Studi pada UKM Sentra Kabupaten Malang). Jurnal Ekonomi MODERNISASI, 10(1), 23-37. https://doi.org/10.21067/jem.v10i1.771

Pakpahan, A. K. (2020). COVID-19 dan implikasi bagi usaha mikro, kecil, dan menengah. Jurnal Ilmiah Hubungan Internasional, 16(1), 1-6. https://doi.org/10.26593/jihi.v0i0.3870.59-64

Peraturan BPK RI. (2002). Sistem Nasional Penelitian, Pengembangan, dan Penerapan Ilmu Pengetahuan dan Teknologi. https://peraturan.bpk.go.id/Home/Details/44462

Pratono, A. H. (2018). Does firm performance increase with risk-taking behavior under information technological turbulence: Empirical evidence from Indonesian SMEs. Journal of Risk Finance, 3(3), 170-178. https://doi.org/10.1108/JRF-10-2017-0170

Ranto, D. W. P. (2016). Pengaruh orientasi kewirausahaan terhadap kinerja UMKM bidang kuliner di Yogyakarta. Jurnal Bisnis, Manajemen, dan Akuntansi, 3(2), 1-11. http://jurnal.amaypk.ac.id/index.php/jbma/article/view/45

Ratnawati, T. \& Hikmah. (2013). Faktor-faktor yang memengaruhi kinerja UKM (Studi kasus UKM di Kabupaten dan Kota Semarang). Jurnal Ilmiah UNTAG, 2(1), 102-113. http://jurnal.untagsmg.ac.id/index.php/sa/article/view/41

Saragih, R. (2017). Membangun usaha kreatif, inovatif, dan bermanfaat melalui penerapan $\begin{array}{lllll}\text { kewirausahaan sosial. Jurnal } & \text { Kewirausahaan. } & 3(2), & 26-34\end{array}$ https://www.academia.edu/download/62846836/223703-membangun-usaha-kreatif-inovatif1_120200406-48380-1yh0v9e.pdf.

Suryani \& Hendryadi. (2015). Metode riset kuantitatif teori dan aplikasi pada penelitian bidang manajemen dan ekonomi Islam. Perpustakaan Nasional: Katalog dalam Terbitan, Edisi 1. https://books.google.co.id/books?id=YHADwAAQBAJ\&printsec=frontcover\#v=onepage \&q\&f= false

Sutejo, B. S. (2015). Financial performance impacts of corporate entrepreneurship. Journal of Management and Business, 15(1), 49-59. https://doi.org/10.24123/jmb.v15i1.41

Utami, Y. \& Kusmantini, T. (2012). Antesedensi manajemen lingkungan proaktif dan konsekuensinya pada kinerja lingkungan dan kinerja bisnis (Studi empiris pada UMKM produk unggulan di DIY). Jurnal Manajemen dan Inovasi dan Bisnis, 2(1), 161-180. http://eprints.upnyk.ac.id/id/eprint/20966

Wahid, N. N. (2017). Pengaruh kemampuan menyusun laporan keuangan dan motivasi terhadap kinerja UKM di Kota Tasikmalaya. Riset Akutansi dan Bisnis, 12(1), 53-68. http://jurnal.unsil.ac.id/index.php/jak/article/view/295

Wolff, J. A., Pett, T. L., \& Ring, J. K. (2015). Small firm growth as a function of both earning orientation and entrepreneurial orientation: An empirical analysis. International Journal of Entrepreneurial Behavior \& Research, 21(5), 709-730. doi: 10.9744/jmk.22.2.99-114

Wulandary, A., Burhanuddin, B., \& Priatna, W. B. (2018). Kinerja wirausaha dan orientasi kewirausahaan pelaku UMKM olahan abon ikan. Jurnal AGRISEP: Kajian Masalah Sosial Ekonomi Pertanian dan Agribisnis, 17(2). 129-138. https://doi.org/10.31186/jagrisep.17.2.129-138 